\title{
INTEGRAL ERROR REPRESENTATION OF HERMITE INTERPOLATING POLYNOMIALS AND RELATED GENERALIZATIONS OF STEFFENSEN'S INEQUALITY
}

\author{
Josip PeČarić, AnAmariJa Perušić Pribanić And KseniJa SmoljaK \\ KALAMIR
}

Abstract. Some representations of Steffensen's inequality are obtained by using Hermite interpolating polynomials. The obtained representations are used to prove new generalizations of Steffensen's inequality for $n$-convex functions and to give some bounds for integrals in these representations.

Mathematics subject classification (2010): 26D15, 26A51.

Keywords and phrases: Steffensen's inequality, Hermite interpolating polynomial, Green's function, $n-$ convex function.

\section{REFERENCES}

[1] R. P. Agarwal And P. J. Y. Wong, Error Inequalities in Polynomial Interpolation and Their Applications, Kluwer Academic Publishers, Dordrecht / Boston / London, 1993.

[2] A. Aglić Aljinović, J. PeČArić AND A. Perušić, Generalizations of Steffensen's inequality via weighted Montgomery identity, Math. Inequal. Appl., 17 (2) (2014), 779-799.

[3] P. R. BEESACK, On the Green's function of an N-point boundary value problem, Pacific J. Math. 12 (1962), 801-812.

[4] P. Cerone And S. S. DRAgomir, Some new bounds for the Čebyšev functional in terms of the first derivative and applications, J. Math. Inequal. 8 (1) (2014), 159-170.

[5] G. GRÜss, Über das Maximum des absoluten Betrages von $\frac{1}{b-a} \int_{a}^{b} f(x) g(x) d x-$ $\frac{1}{(b-a)^{2}} \int_{a}^{b} f(x) d x \int_{a}^{b} g(x) d x$, Math. Z. 39 (1935), 215-226.

[6] A. Yu. LEVIN, Some problems bearing on the oscillation of solutions of linear differential equations, Soviet Math. Dokl. 4 (1963), 121-124.

[7] J. E. PeČArić, F. Proschan and Y. L. Tong, Convex functions, partial orderings, and statistical applications, Mathematics in science and engineering 187, Academic Press, 1992.

[8] J. PeČARIĆ AND K. SMOLJAK, Steffensen type inequalities involving convex functions, Math. Inequal. Appl. 18(1) (2015), 363-378.

[9] J. PeČARIĆ, K. SMOlJak KalamiR And S. VARošAnec, Steffensen's and related inequalities (A comprehensive survey and recent advances), Monograhps in inequalities 7, Element, Zagreb, 2014.

[10] J. F. STEFFENSEN, On certain inequalities between mean values and their application to actuarial problems, Skand. Aktuarietids. (1918), 82-97. 